\title{
Spermostatic activity of Eugenia brejoensis and Myroxylon peruiferum essential oils toward human spermatozoa
}

José Adelson Alves do Nascimento Junior ${ }^{1,2^{*}}$, Clovis Macêdo Bezerra Filho ${ }^{2}$, Thiago Henrique Florencio de Oliveira ${ }^{1,3}$, Alexandre Gomes da Silva ${ }^{4,5}$, Patricia Cristina Bezerra-Silva ${ }^{6,}$ Patricia Maria Guedes Paiva ${ }^{2}$, Marcia Vanusa da Silva ${ }^{2,5}$, Daniela Maria do Amaral Ferraz Navarro ${ }^{6}$, Luis Claudio Nascimento da Silva ${ }^{1,7}$ and Maria Tereza dos Santos Correia ${ }^{2,5}$

\footnotetext{
${ }^{1}$ ASCES UNITA, Av. Portugal, 584 - Universitário, 55016-901, Caruaru - Pernambuco, Brazil.

${ }^{2}$ Departamento de Bioquímica, Universidade Federal de Pernambuco, 50670-420 Recife, Pernambuco, Brazil.

${ }^{3}$ Universidade Federal da Paraiba, Cidade Universitária, s/n - Castelo Branco III, 58051-085, João Pessoa - Paraíba, Brazil.

${ }^{4}$ Departamento de Antibióticos, Centro de Biociências, Universidade Federal de Pernambuco. Av. Prof. Moraes Rego, 1235 - Cidade Universitária, CEP: 50670-901, Recife, Brazil.

${ }^{5}$ Núcleo de Bioprospecção e Conservação da Caatinga, Instituto Nacional do Semiárido/Ministério da Ciência, Tecnologia, Inovações e Comunicações. Av. Francisco Lopes de Almeida, S/N - Serrotão, CEP: 58429-970, Campina Grande, Brazil.

${ }^{6}$ Departamento de Química Fundamental, Universidade Federal de Pernambuco, Recife-PE, Brazil ${ }^{7}$ Universidade CEUMA, Rua Josué Montello 165.075 - 120, São Luís, Brazil.
}

Received 4 June, 2018; Accepted 25 June, 2018

In this study, the in vitro spermostatic action, hemolytic action in combination of parabens of two essential oils (EOs) from Eugenia brejoensis Mazin (Myrtaceae, EbEO) and Myroxylon peruiferum $\mathrm{L}$. (Fabaceae, MpEO) is reported, in addition to the first chemical characterization of MpEO. The EOs were obtained by hydrodistillation and characterized by gas chromatography-mass spectrometry (GC-MS). Different concentrations of both EOs (25 to $400 \mu \mathrm{g} / \mathrm{mL}$ ) were mixed with human ejaculate and sperm motility was assessed after 5,15 and $30 \mathrm{~min}$. A total of 44 compounds were identified in MpEO; the major components were spathulenol, $\alpha$-pinene, caryophyllene oxide, limonene and $\beta$-elemene. Both EOs exhibited spermostatic action in a dose-dependent manner. The best results were obtained for EbEO at all treatment times, showing $\mathrm{IC}_{50}$ values of $454.75 \mu \mathrm{g} / \mathrm{mL}(5 \mathrm{~min}), 417.68 \mu \mathrm{g} / \mathrm{mL}(15 \mathrm{~min})$ and $403.93 \mu \mathrm{g} / \mathrm{mL}$ (30 min). M. peruiferum also showed significant immobilizing potential with IC $_{50}$ values of $620.39 \mu \mathrm{g} / \mathrm{mL}(5 \mathrm{~min}), 652.70 \mu \mathrm{g} / \mathrm{mL}(15 \mathrm{~min})$ and $579.37 \mu \mathrm{g} / \mathrm{mL}(30 \mathrm{~min})$. Both oils showed low cytotoxicity against human erythrocytes. This is the first report on human spermostatic action for EOs from $E$. brejoensis and $M$. peruiferum which has antimicrobial activity and low cytotoxicity. These results suggest the need for further research on toxicological aspects of both EOs and their components in order to develop new pharmaceutical preparations using them as leader compounds.

Key words: Eugenia brejoensis and Myroxylon peruiferum essential oils, spermostatic activity, human spermatozoa. 


\section{INTRODUCTION}

Several contraceptive methods are described in the medical literature as alternatives to avoid unplanned pregnancy. These approaches include different compounds from various chemical classes, of various action mechanisms and with different levels of effectiveness. Barrier methods, for example, consist of the use of substances that prevent fertilization of the ovum by sperm by establishing physical or chemical barriers (Kumar et al., 2012). Vaginal spermicides, including creams, gels and foaming aerosols are examples of chemical barriers (Batár, 2010). Spermicidal substances are designed to prevent pregnancy through death or immobilization of spermatozoa so that they are unable to reach the oocyte and fertilize it (Schreiber et al., 2006). Despite their advantages, they are based mostly on nonoxynol-9, a compound that is capable of causing side-effects such as cervical and vaginal irritability and potentially favoring the emergence of infectious microorganisms and/or altering the growth of lactobacilli (Ojha et al., 2003). There is urgent need for replacement of such agents with safer and more effective alternatives such as natural contraceptives.

In this context, it is important to search for new spermicidal compounds from plants, especially those endemic to different and under-exploited ecosystems, such as the Caatinga (a biome exclusive to Brazil). This area is marked by extreme environmental conditions typical of a semi-arid tropical climate, such as high temperatures (annual average temperature above $25^{\circ} \mathrm{C}$ ) and scarce and erratic rainfall with long periods of drought. It is believed that these climatic features play an essential role in the production of bioactive metabolites by plants of the Caatinga (de Albuquerque et al., 2012). Such metabolites provide a range of proven biomedical applications (de Oliveira et al., 2012; da Silva et al., 2013), thereby encouraging the search for new compounds from plants of the Caatinga.

This study aimed to evaluate the spermostatic activity of essential oils from two plants collected in the Caatinga: Eugenia brejoensis Mazin and Myroxylon peruiferum L. The first plant, E. brejoensis (Myrtaceae), is a recently described species first recorded from humid, highland forests, called brejos, in the Caatinga of Pernambuco State, Brazil. Later collections documented an expanded distribution now known to include other states of the Brazilian Northeast (Paraiba, Alagoas and Sergipe) and Southeast (Espírito Santo) and showed that the species occurs in both the Caatinga and Atlantic forest domains (Mazine and Souza, 2008; Giaretta and Peixoto, 2014). On the other hand, M. peruiferum (Fabaceae) is a wellknown species with a wide distribution in Brazil and

\section{MATERIALS AND METHODS}

\section{Collection of plant}

Samples of leaves from $E$. brejoensis and $M$. peruiferum were collected from the "Parque Nacional do Catimbau" (Catimbau National Park, Buíque, Pernambuco, Brazil) in September, 2012. Botanical identification was done at the Herbarium of the Instituto Agronômico de Pernambuco (Agronomic Institute of Pernambuco; IPA-PE, Brazil) and specimen vouchers were deposited in the same herbarium (IPA 84.033 and IPA 84.113, respectively).

\section{Extraction of the essential oils}

Approximately, $200 \mathrm{~g}$ of powdered leaves of each plant (pre-dried at room temperature and ground in a mill) were subjected to hydrodistillation by heating for $3 \mathrm{~h}$ in a Clevenger-type apparatus. Each essential oil layer was separated, dried over anhydrous sodium sulfate and stored in a hermetically sealed glass vial. The essential oils were named from $E$. brejoensis as EbEO and from $M$. Peruiferum as MpEO. They were stored at $4^{\circ} \mathrm{C}$ prior to each assay. This protocol was repeated 3 times at least .

\section{GC and GCMS analyses}

Gas chromatographic-mass spectrometric (MS) analyses were carried out using an Agilent 5975C Series quadrupole GC/MSD (Agilent Technologies, Palo Alto, USA) instrument equipped with an Agilent J\&W non-polar DB-5 fused silica capillary column $(60 \mathrm{~m} \times$ $0.25 \mathrm{~mm}$ i.d.; film thickness $0.25 \mu \mathrm{m}$ ). For each sample, $1 \mu \mathrm{L}$ was injected in split mode $(50: 1)$ with the injector temperature set to $250^{\circ} \mathrm{C}$.

The GC oven temperature was set at $40^{\circ} \mathrm{C}$, held for $2 \mathrm{~min}$, increased to $230^{\circ} \mathrm{C}$ at $4^{\circ} \mathrm{C} / \mathrm{min}$, then held for $5 \mathrm{~min}$. Helium $(\mathrm{He})$ carrier gas flow $(1 \mathrm{~mL} / \mathrm{min})$ was maintained at a constant pressure of 7.0 psi. MS Source and quadruple temperatures were set at 230 and $150^{\circ} \mathrm{C}$, respectively. Mass spectra were taken at $70 \mathrm{eV}$ (in El mode) with a scanning speed of 1.0 scan from 35 to $350 \mathrm{~m} / \mathrm{z}$. The same conditions were used in the GC analysis performed in a Thermo Fisher Scientific (Waltham, MA, USA) Trace GC Ultra gas chromatograph equipped with a flame ionization detector (FID), a split/splitless injector and a Hamilton Bonaduz (Bonaduz

Switzerland) HB-5 fused silica capillary column $(30 \mathrm{~m} \times 0.25 \mathrm{~mm}$; film thickness $0.25 \mu \mathrm{m}$ ). The composition of essential oil was expressed in the form of percentages of total peak area as recorded by the GC-FID. The GC analyses were performed in triplicate. The medium percentage of peaks were processed.

Initial identification of the individual components of the essential oils was carried out by comparison with previously reported values of retention indexes $(\mathrm{RI})$, obtained by co-injection of oil samples and $\mathrm{C}_{9}-\mathrm{C}_{30}$ linear hydrocarbons and calculated according to the Van den Dool and Kratz equation (Van Den Dool and Dec Kratz, 1963; Adams, 2009). Subsequently, the MS acquired for each component was matched with those stored in the mass spectral library of the GC-MS system (MassFinder 4, NIST08 and Wiley Registry ${ }^{\mathrm{TM}}$ 9th Edition) and with other published mass spectral data.

\section{${ }^{*}$ Corresponding author. E-mail: juniior.aalves@live.com.}

Author(s) agree that this article remain permanently open access under the terms of the Creative Commons Attribution License 4.0 International License 


\section{Analysis of immobilizing activity}

Semen samples were collected by masturbation from 12 fertile volunteers who had been pre-tested, were non-smoking, healthy, aged 18 to 45 years, and whose sperm showed normal morphology (> 60\%), motility and viability more than 40 and $70 \%$, respectively. Semen samples were collected after sexual abstinence of 48 to 120 $\mathrm{h}$, as recommended by the WHO standard protocol (World Health Organization, 2010). A routine semen analysis was performed immediately after coagulation, followed by reliquefaction at room temperature. A free and informed consent form was signed by each volunteer before participation in the study. All experiments were performed according to ethical standards and were approved by the Ethics Committee of ASCES College (Caruaru, Brazil), under license number 02604312.6.0000.5203.

Different concentrations $(25,50,100,200$ and $400 \mu \mathrm{g} / \mathrm{mL})$ of each oil (prewarmed to $37^{\circ} \mathrm{C}$ ) were mixed with human ejaculate at a $1: 1$ volume ratio. A solution of warmed DMSO (5\%), diluted in phosphate-buffered saline (PBS; pH 7.4), was used as a control. Motility assessment was performed by putting $10 \mu \mathrm{L}$ of each experimental mixture (Semen + EO or Semen + Control) on prewarmed slides, and at least 10 fields were viewed for a total count of 200 spermatozoa for each slide (Paul and Kang, 2011). The tests were carried out in triplicate for each sample after incubation for 5,15 and $30 \mathrm{~min}$. Sperm motility was assessed following the WHO protocol for seminal processing (World Health Organization, 2010). Tests were performed independently and six patients were tested for each essential oil.

\section{Hemolytic assay}

Blood (5 to $10 \mathrm{ml}$ ) was obtained from healthy volunteers by venipuncture and placed in heparinized tubes, after written informed consent was obtained. Human erythrocytes were isolated by centrifugation $\left(1,500 \mathrm{rpm}, 10 \mathrm{~min}\right.$ at $\left.4^{\circ} \mathrm{C}\right)$. The erythrocytes were washed three times with phosphate-buffered saline (PBS; $\mathrm{pH} 7.4$ ). Each tube received $1.1 \mathrm{~mL}$ of erythrocyte suspension $(1 \%)$ and 0.4 $\mathrm{mL}$ of various extract concentrations $(0.15625$ to $2.5 \mathrm{mg} / \mathrm{mL})$. The controls were only solvent (negative) and Quillaja saponin $(0.0025 \%$, positive). After 60 min incubation, cells were centrifuged and the absorbance of supernatant was recorded at $540 \mathrm{~nm}$. The hemolytic activity was expressed by the following formula (de Oliveira et al., 2012):

Hemolytic activity $(\%)=(A s-A b) \times 100 /(A c-A b)$

where $\mathrm{Ab}=$ solvent absorbance, $\mathrm{As}$ = sample absorbance, and Ac = saponin absorbance.

\section{Statistical analysis}

The results are expressed as mean \pm standard deviation (SD). Statistical significance was determined by Student $t$ and analysis of variance (ANOVA) tests comparing treated groups with untreated control. A p-value of $<0.05$ was considered to be statistically significant. In all graphs, the bars represent the mean value \pm SD. Determinations of $\mathrm{IC}_{50}$ (concentration of $50 \%$ immobilized spermatozoa) and $\mathrm{HC}_{50}$ (the concentration needed for $50 \%$ of hemolysis) were performed by linear regression.

\section{RESULTS AND DISCUSSION}

The chemical composition of the oils used in this paper was performed by GC-MS. As shown in Table 1, 47 and 41 components were detected in the oils of $M$. peruiferum (MpEO) and E. brejoensis (EbEO), respectively. Of these, 44 compounds were identified in MpEO (which corresponds to $96.38 \%$ of the total). This oil was found to be rich in sesquiterpenes (63.37\%) and monoterpenes $(21.31 \%)$. Its major components $(58.84 \%)$ were spathulenol (13.29\%), a-pinene (9.64\%), caryophyllene oxide $(7.27 \%)$, limonene $(7.17 \%)$, $\beta$-elemene $(6.79 \%)$, bicyclogermacrene $(5.49 \%), \beta$-bourbonene $(4.96 \%)$ and $\alpha$-muurolene (4.23\%) (Table 1). On the other hand, EbEO composed almost entirely of sesquiterpenes (both sesquiterpene hydrocarbons and oxygenated sesquiterpenes; 62.66 and $26.64 \%$, respectively). Its major compounds were $\delta$-cadinene $(22.6 \%), \quad \beta-(E)$ caryophyllene $(14.4 \%)$, a-muurolol $(9.34 \%)$, a-cadinol $(8.49 \%)$ and bicyclogermacrene (7.93\%) (da Silva et al., 2015).

The effects of EbEO and MpEO on human spermatozoa motility is as shown in Figure 1. The essential oil from $E$. brejoensis showed the best spermicide activity. When treated with EbEO, significant immobilizing action was observed with all tested concentrations and at all times as compared to controls $(p<0.05)$, except at a concentration of $25 \mu \mathrm{g} / \mathrm{mL}$. The spermostatic activity of EbEO was time- and dose-dependent and ranged from 8.53 to $42.70 \%$ at $5 \mathrm{~min}$, from 9.38 to $44.10 \%$ at $15 \mathrm{~min}$, and from 9.60 to $47.56 \%$ at $30 \mathrm{~min}$.

The $\mathrm{IC}_{50}$ values were $454.75,417.68$ and $403.93 \mu \mathrm{g} / \mathrm{mL}$ at 5,15 and $30 \mathrm{~min}$, respectively. Previous studies has showed the biomedical potentials of oils from Eugenia plants (Ogunwande et al., 2005; Siebert et al., 2015), including antifertility activities for Eugenia jambolana (Rajasekaran et al., 1988). Similarly, the presence of $\beta$ caryophyllene, a chemical component identified in Eugenia brejoensis, has been reported in the oil of Trachyspermum ammi which also has spermicidal action (Paul and Kang, 2011). Other constituents identified in EbEO such as bicyclogermacrene, $\delta$-cadinene, $a$ muurolol and $\alpha$-cadinol are reported in other bioactive essential oils (Martins et al., 2015; Karapandzova et al., 2014; Su et al., 2015).

Regarding the action of $\mathrm{MpEO}$, significant inhibition was found at $50 \mu \mathrm{g} / \mathrm{mL}$ after 15 and $30 \mathrm{~min}$ of incubation, and at higher concentrations $(100,200$ and $400 \mu \mathrm{g} / \mathrm{mL})$ in all treatment periods $(p<0.05)$. The immobilizing values were also dose-dependent and ranged from 6.2 to $33.33 \%$ at $5 \mathrm{~min}, 7.6$ to $32.73 \%$ at $15 \mathrm{~min}$, and from 9.66 to $36.66 \%$ at $30 \mathrm{~min}$. The $\mathrm{IC}_{50}$ values at 5,15 and $30 \mathrm{~min}$ were $620.39,652.70$ and $579.37 \mu \mathrm{g} / \mathrm{mL}$, respectively. It is worth emphasizing that there are no reports in the literature regarding contraceptive potential for the genre Myroxylon. As part of its phytochemical composition, $M$. peruiferum possesses, volatile oils, esters, alcohols, triterpene alkaloids, phenols, proteins and glycosides (Schwarcz et al., 2014).

Chemical components identified in $M$. peruiferum 
Table 1. Identification of constituents of the essential oil obtained from Eugenia brejoensis and Myroxylon peruiferum.

\begin{tabular}{|c|c|c|c|c|c|c|}
\hline \multirow{2}{*}{ Number } & \multirow{2}{*}{ Identify compound $^{\mathrm{a}}$} & \multirow{2}{*}{$\begin{array}{c}\text { Retention } \\
\text { times }\end{array}$} & \multicolumn{2}{|c|}{ Retention indices } & \multicolumn{2}{|c|}{ Content (as $\%$ of total oil) + SD } \\
\hline & & & Determined $^{\mathbf{b}}$ & Literature $^{c}$ & E. brejoensis & M. peruiferum \\
\hline 1 & a-Pinene & 9.396 & 932 & 932 & - & $9.64 \pm 0.20$ \\
\hline 2 & Thuja-2.4(10)-diene & 10.132 & 952 & 953 & - & $0.23 \pm 0.01$ \\
\hline 3 & $\beta$-Pinene & 10.945 & 974 & 974 & - & $0.44 \pm 0.01$ \\
\hline 4 & Myrcene & 11.550 & 991 & 988 & - & $0.15 \pm 0.03$ \\
\hline 5 & $\rho$-Cymene & 12.753 & 1024 & 1020 & - & $0.10 \pm 0.04$ \\
\hline 6 & Limonene & 12.903 & 1028 & 1024 & - & $7.17 \pm 0.38$ \\
\hline 7 & $\mathrm{y}$-Terpinene & 15.238 & 1058 & 1054 & - & $0.12 \pm 0.07$ \\
\hline 8 & Terpinolene & 16.541 & 1088 & 1086 & - & $0.05 \pm 0.02$ \\
\hline 9 & a-Campholenal & 16.978 & 1126 & 1122 & - & $0.95 \pm 0.04$ \\
\hline 10 & trans-Pinocarveol & 16.978 & 1138 & 1135 & - & $0.38 \pm 0.06$ \\
\hline 11 & trans-Verbenol & 17.208 & 1144 & 1140 & - & $1.17 \pm 0.15$ \\
\hline 12 & Pinocarvone & 17.869 & 1163 & 1160 & - & $0.08 \pm 0.05$ \\
\hline 13 & a-Phellandre-8-ol & 18.024 & 1167 & 1166 & - & $0.20 \pm 0.00$ \\
\hline 14 & Terpinen-4-ol & 19.089 & 1177 & 1174 & - & $0.41 \pm 0.01$ \\
\hline 15 & trans-Carveol & 19.878 & 1219 & 1215 & - & $0.22 \pm 0.01$ \\
\hline 16 & Isovaleric acid & 20.489 & 1234 & 1232 & - & $0.22 \pm 0.01$ \\
\hline 17 & a-Cubebene & 24.395 & 1351 & 1348 & $1.28 \pm 0.02$ & $1.19 \pm 0.01$ \\
\hline 18 & $\alpha$-Copaene & 25.221 & 1378 & 1374 & $1.23 \pm 0.01$ & $2.63 \pm 0.11$ \\
\hline 19 & $\beta$-Bourbonene & 25.517 & 1387 & 1387 & - & $4.96 \pm 0.21$ \\
\hline 20 & US & 25.687 & 1392 & - & - & $0.66 \pm 0.02$ \\
\hline 21 & $\beta$-Elemene & 25.742 & 1394 & 1389 & $0.84 \pm 0.01$ & $6.79 \pm 0.20$ \\
\hline 22 & US & 26.177 & 1407 & - & - & $0.55 \pm 0.03$ \\
\hline 23 & a-Gurjunene & 26.344 & 1413 & 1409 & $1.56 \pm 0.02$ & - \\
\hline 24 & trans-Caryophyllene & 26.619 & 1422 & 1417 & $8.43 \pm 0.09$ & $3.51 \pm 0.11$ \\
\hline 25 & $\beta$-Copaene & 26.955 & 1432 & 1430 & $0.53 \pm 0.01$ & - \\
\hline 26 & Aromadendrene & 27.261 & 1442 & 1439 & $0.14 \pm 0.01$ & - \\
\hline 27 & a-Himachalene & 27.395 & 1447 & 1449 & $1.78 \pm 0.02$ & - \\
\hline 28 & a-Humulene & 27.685 & 1456 & 1452 & $0.28 \pm 0.01$ & $1.19 \pm 0.06$ \\
\hline 29 & Caryophyllene $<9$-epi-(E)-> & 27.913 & 1464 & 1464 & $1.67 \pm 0.02$ & $0.22 \pm 0.00$ \\
\hline 30 & Cadina-1(6),4-diene $<$ trans-> & 28.354 & 1477 & 1475 & $1.97 \pm 0.03$ & - \\
\hline 31 & Y-Muurolene & 28.392 & 1479 & 1478 & $2.50 \pm 0.03$ & $0.42 \pm 0.02$ \\
\hline 32 & Germacrene D & 28.540 & 1486 & 1484 & - & $1.06 \pm 0.04$ \\
\hline 33 & $\beta$-Selinene & 28.695 & 1489 & 1489 & $0.88 \pm 0.01$ & $1.63 \pm 0.04$ \\
\hline 34 & a-Selinene & 28.961 & 1498 & 1498 & - & $1.22 \pm 0.03$ \\
\hline 35 & Bicyclogermacrene & 29.007 & 1499 & 1500 & $4.27 \pm 0.10$ & $5.49 \pm 0.20$ \\
\hline 36 & a-Muurolene & 29.114 & 1503 & 1500 & $2.61 \pm 0.06$ & $4.23 \pm 0.50$ \\
\hline 37 & Germacrene A & 29.273 & 1508 & 1508 & - & $2.67 \pm 0.08$ \\
\hline 38 & Y-Cadinene & 29.554 & 1517 & 1513 & $5.37 \pm 0.05$ & $0.83 \pm 0.02$ \\
\hline 39 & $\delta$-Cadinene & 29.807 & 1526 & 1522 & $15.57 \pm 0.07$ & $2.84 \pm 0.02$ \\
\hline 40 & Cadina-1,4-diene <trans-> & 30.062 & 1535 & - & $0.35 \pm 0.01$ & $0.18 \pm 0.02$ \\
\hline 41 & $\alpha$-Cadinene & 30.240 & 1541 & 1537 & $1.03 \pm 0.01$ & $0.13 \pm 0.08$ \\
\hline 42 & a-Calacorene & 30.386 & 1546 & 1544 & $0.72 \pm 0.03$ & $0.37 \pm 0.01$ \\
\hline 43 & US & 30.693 & 1556 & - & - & $0.79 \pm 0.01$ \\
\hline 44 & Palustrol & 31.142 & 1572 & 1567 & $1.04 \pm 0.01$ & - \\
\hline 45 & Spathulenol & 31.411 & 1581 & 1577 & $10.04 \pm 0.20$ & $13.29 \pm 0.48$ \\
\hline 46 & Caryophyllene oxide & 31.575 & 1586 & 1582 & $4.81 \pm 0.14$ & $7.27 \pm 0.27$ \\
\hline 47 & Viridiflorol & 31.861 & 1596 & 1592 & $1.09 \pm 0.01$ & - \\
\hline 48 & Salvial-4(14)-em-1-one & 31.885 & 1597 & 1594 & - & $0.96 \pm 0.05$ \\
\hline 49 & Guaiol & 32.017 & 1602 & 1600 & $1.39 \pm 0.01$ & - \\
\hline 50 & Ledol & 32.175 & 1607 & 1602 & $2.44 \pm 0.02$ & - \\
\hline
\end{tabular}


Table 1. Cont'd.

\begin{tabular}{|c|c|c|c|c|c|c|}
\hline 51 & $\beta$-Oplopenone & 32.358 & 1613 & 1607 & $0.97 \pm 0.01$ & - \\
\hline 52 & Cubenol <1,10-di-epi-> & 32.505 & 1619 & 1618 & $0.75 \pm 0.01$ & - \\
\hline 53 & Cubenol $<1$-epi-> & 32.851 & 1631 & 1627 & - & $0.15 \pm 0.01$ \\
\hline 54 & UC & 32.881 & 1633 & - & $0.27 \pm 0.07$ & - \\
\hline 55 & UC & 32.981 & 1635 & - & $2.13 \pm 0.01$ & - \\
\hline 56 & Aromadendrene eposxide <allo-> & 33.148 & 1642 & 1639 & - & - \\
\hline 57 & a-Muurolol & 33.231 & 1645 & 1640 & $5.25 \pm 0.04$ & $0.12 \pm 0.04$ \\
\hline 58 & a-Cadinol & 33.612 & 1659 & 1652 & $9.24 \pm 0.17$ & - \\
\hline 59 & Eudesma-4(15).7-dien-1 $\beta$-ol & 34.447 & 1689 & 1687 & - & $0.33 \pm 0.27$ \\
\hline 60 & US & 34.582 & 1694 & - & - & $0.16 \pm 0.08$ \\
\hline 61 & US & 35.050 & 1711 & - & - & $0.66 \pm 0.13$ \\
\hline \multirow[t]{7}{*}{62} & US & 35.307 & 1721 & - & - & $0.49 \pm 0.13$ \\
\hline & Monoterpenes & - & - & - & - & 21.31 \\
\hline & Sesquiterpenes & - & - & - & 90.03 & 63.37 \\
\hline & Unidentified sesquiterpenes (US) & - & - & - & - & 3.62 \\
\hline & Fatty acids & - & - & - & - & 0.22 \\
\hline & Unidentified compounds & - & - & - & 2.40 & 9.84 \\
\hline & Total & - & - & - & 92.43 & 98.36 \\
\hline
\end{tabular}

${ }^{a}$ Constituents listed in order of elution on a non-polar DB- 5 column; ${ }^{b}$ Retention indices (RI) calculated from retention times in relation to those of a series of $\mathrm{C}_{9}-\mathrm{C}_{30}$. $n$-alkanes on a $30 \mathrm{~m}$ DB-5 capillary column; ${ }^{\circ}$ Values taken from Adams (2009).

A)

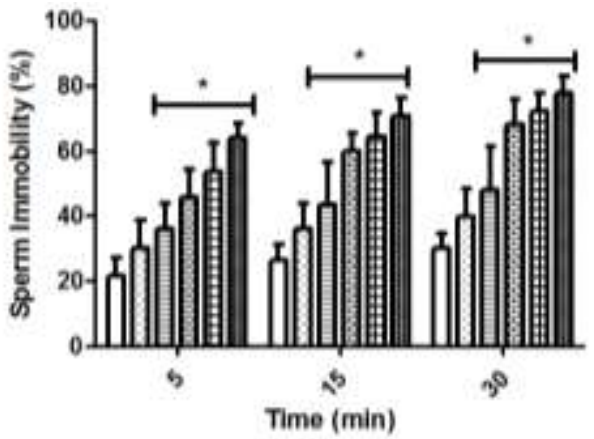

B)

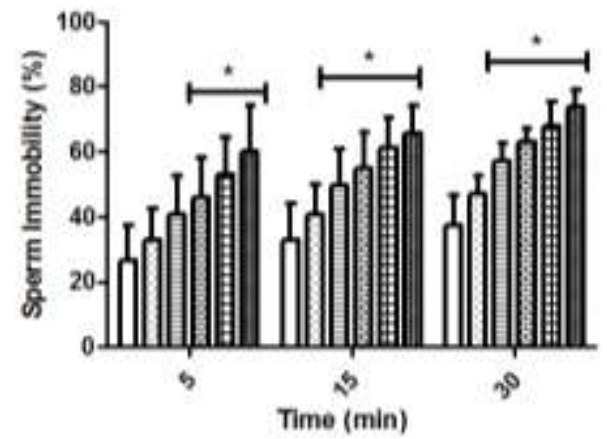

Figure 1. Spermostatic effect of essential oils from Eugenia brejoensis and Myroxylon peruiferum, respectively.

essential oil such as $\alpha$-pinene, $y$-muuroleno, spathulenol and caryophyllene oxide were not reported as contraceptive actives in previous studies. On the other hand, some major components (such as a-pinene, $\mathrm{y}^{-}$ muurolene, caryophyllene oxide) have been detected in essential oils antimicrobial, antioxidant, and gastroprotective activities (Almeida et al., 2015; Saraswathy et al., 2010; Policegoudra et al., 2012).

The cellular toxicity were evaluated using human erythrocytes as test system, both essential oils showed low toxicity with $\mathrm{HC}_{50}$ of 8.66 and $6.85 \mathrm{mg} / \mathrm{mL}$, for MPEO and EBEO, respectivelly. These concentrations are higher than $I_{50}$ values found for both oils.

\section{Conclusion}

This study demonstrated that essential oils from $E$. brejoensis and $M$. peruiferum show a potential spermostatic effect on human sperm with low cytotoxicity. Future studies, including the identification of active compounds in each essential oil, their action mechanisms and in vivo activity, are necessary to support the use of these essential oils to develop new pharmaceutical preparations.

\section{CONFLICT OF INTERESTS}

The authors have declared any conflict of interests.

\section{ACKNOWLEDGEMENTS}

The authors appreciate MCT/CNPq and NANOBIOTECBrazil from CAPES for financial support and Fundacão 
de Amparo à Ciência and Tecnologia do Estado de Pernambuco (FACEPE) for research grants. They are very grateful to the Instituto Chico Mendes de Conservação da Biodiversidade (ICMBio) for authorizing collections in PARNA do Catimbau (Sisbio 16.806).

\section{REFERENCES}

Adams RP (2009). Identification of essential oil components by gas chromatography/mass spectroscopy. Journal of the American Society for Mass Spectrometry 6(8):671-672.

Almeida PM, Magalhães RM, Torres DM, Cavalcante RC, Mota FSX, Coelho EMAO, Diniz LRL (2015). Gastroprotective effect of alphapinene and its correlation with antiulcerogenic activity of essential oils obtained from Hyptis species. Pharmacognozy Magazine 11:123130.

Batár I (2010). State-of-the-art of non-hormonal methods of contraception: II. Chemical barrier contraceptives. The European Journal of Contraception and Reproductive Health Care 15:89-95.

da Silva AG, Alves RC, Filho CM, Bezerra-Silva PC, Santos LM, Foglio MA, Navarro DM, Silva MV, Correia MT (2015).Chemical composition and larvicidal activity of the essential oil from leaves of Eugenia brejoensis Mazine (Myrtaceae). Journal of Essential Oil Bearing Plants 18(6):1441-1447.

da Silva LC, Sandes JM, de Paiva MM, de Araújo JM, Figueiredo RC, da Silva MV, Correia MT (2013). Anti-Staphylococcus aureus action of three Caatinga fruits evaluated by electron microscopy. Natural Products Research 27:1492-1496.

de Albuquerque UP, de Lima Araújo E, El-Deir AC, de Lima AL, Souto A, Bezerra BM, Ferraz EM, Maria Xavier Freire E, Sampaio EV, LasCasas FM, de Moura GJ (2012). Caatinga revisited: ecology and conservation of an important seasonal dry forest. The Scientific World Journal 2012:1-18.

de Oliveira YL, Nascimento da Silva LC, da Silva AG, Macedo AJ, Araújo JM, Correia MT, Silva MV (2012). Antimicrobial activity and phytochemical screening of Buchenavia tetraphylla (Aubl.) RA Howard (Combretaceae: Combretoideae). The Scientific World Journal 2012:1-6.

Giaretta A, Peixoto AL (2014). New records of Eugenia brejoensis Mazine (Myrtaceae) and complementary description. Check List 10(5):1176-1178.

Karapandzova M, Stefkova G, Cvetkovikj I, Trajkovska-Dokik E, Kaftandzieva A, Kulevanova S (2014). Chemical composition and antimicrobial activity of the essential oils of Pinus peuce (Pinaceae) growing wild in R. Macedonia. Natural Product Communications 9:1623-1628.

Kumar D, Kumar A, Prakash O (2012). Potential antifertility agents from plants: A comprehensive review. Journal of Ethnopharmacology 140:1-32.

Martins CD, Nascimento EA, de Morais SA, de Oliveira A, Chang R, Cunha L, Martins MM, Martins CH, Moraes TD, Rodrigues PV, Silva CV (2015). Chemical Constituents and Evaluation of Antimicrobial and Cytotoxic Activities of Kielmeyera coriacea Mart. \& Zucc. Essential Oils. Evidence-Based Complementary and Alternative Medicine 2015:842047.

Mazine FF, Souza VC (2008). A new species of Eugenia (Myrtaceae) from north-eastern Brazil. Botanical Journal of the Linnean Society 158:775-777.

Ogunwande IA, Olawore NO, Ekundayo O, Walker TM, Schmidt JM, Setzer WN (2005). Studies on the essential oils composition, antibacterial and cytotoxicity of Eugenia uniflora L. International Journal of Aromatherapy 15:147-152.

Ojha P, Maikhuri JP, Gupta G (2003) Effect of spermicides on Lactobacillus acidophilus in vitro nonoxynol-9 vs. Sapindus saponins. Contraception 68:135-138.
Paul S, Kang SC (2011). In vitro determination of the contraceptive spermicidal activity of essential oil of Trachyspermum ammi (L.) Sprague ex Turrill fruits. New Biotechnology 28:684-690.

Policegoudra RS, Goswami S, Aradhya SM, Chatterjee S, Datta S, Sivaswamy R (2012). Bioactive constituents of Homalomena aromatica essential oil and its antifungal activity against dermatophytes and yeasts. Journal of Medical Mycology 22:83-87.

Rajasekaran M, Bapna JS, Lakshmanan S, Nair AR, Veliath AJ, Panchanadam M (1988). Antifertility effect in male rats of oleanolic acid, a triterpene from Eugenia jambolana flowers. Journal of Ethnopharmacology 24:115-121.

Saraswathy A, Shakila R, Lavanya SM, Arunmozhidevi A (2010). Essential oil constituents of Illicium griffithii and its antimicrobial activity. Pharmacognozy Magazine 6:208-211.

Schreiber CA, Meyn LA, Creinin MD, Barnhart KT, Hillier SL (2006). Effects of Long-Term Use of Nonoxynol-9 on Vaginal Flora. Obstetrics and Gynecology 107:136-43.

Schwarcz KD, Bajay MM, Macrini CM, Salazar VL, Souza AP, Pinheiro JB, Brancalion PH, Rodrigues RR, Zucchi MI (2014). Microsatellite markers for the cabreuva tree, Myroxylon peruiferum (Fabaceae), an endangered medicinal species from the Brazilian Atlantic Forest. Genetic and Molecular Research 13:6920-6925.

Siebert DA, Tenfen A, Yamanaka CN, de Cordova CM, Scharf DR, Simionatto EL, Alberton MD (2015). Evaluation of seasonal chemical composition, antibacterial, antioxidant and anticholinesterase activity of essential oil from Eugenia brasiliensis Lam. Natural Product Research 29:289-292.

Su YC, Hsu KP, Wang El, Ho CL (2015). Chemical composition and anti-mildew activities of essential oils from different parts of Michelia compressa var. formosana. Natural Product Communications 10:665668.

Van Den Dool H, Dec Kratz P (1963). A generalization of the retention index system including linear temperature programmed gas-liquid partition chromatography. Jounal of Chromatography A 11:463-471.

World Health Organization (2010). Department of Reproductive Health and Research. WHO laboratory manual for the examination and processing of human semen. 5th ed. edition. Geneva (Switzerland). 